\title{
Exploring Terrorism through Criminological Theories
}

\section{Clairissa Breen}

\begin{abstract}
This paper is a theoretical examination of terrorism using aspects of strain, control, and learning theories. This paper argues that, despite difficulties in defining terrorism within the confines of the criminological discourse and identifying terrorists as criminals, these theories can explain the formation and continuation of terrorist groups, as well as why an individual may decide to become a terrorist. Specifically, strain and control theories apply to terrorism recruitment and why individuals join terrorist groups or become active in terrorism. Learning theories are used to examine the role of both formal and informal terrorist training camps and school. They can also be applied to the prevalence of information-sharing through the Internet, both for members of terrorist groups and for those individuals who seek to become involved in terrorist activity without membership in an organization.
\end{abstract}

\section{Introduction: Terrorism and Criminology}

Terrorism is a combination of criminal activities (Hamm, 2007), engaged in by groups or individuals with a variety of motives, goals and means (Albini, 2001; Silke, 2008; Hewitt, 2000). These groups constantly adapt to their physical, social and political environments (Hamm, 2007) and can be distinguished by their manipulation, exploitation and use of the resources of their enemy or target (Kupperman, Opstal and Williamson, 1982; Chermak 2003). Their goal is to reach the greatest number of victims and supporters, either overtly or through symbolic threats (Berks, 1990: Price, 1977: Combs, 2006: Crenshaw, 1988). Terrorists themselves cannot be identified by specific physical or behavioral characteristics. Terrorists can be drawn from anywhere: any social or educational background, any religious group, any ethnicity, either gender, and any age (Hudson, 1999).

This paper broadly examines three types of criminological theory that can serve as a solid basis for a criminological explanation for terrorism and terrorist action. Each of these theories addresses a different aspect of terrorism. Strain theories help explain the process of terrorist recruitment. Control and learning theories are essential to explaining individual behavior; this includes what factors influence an individual's choice to become a terrorist or the situations and conditions that foster an increase in a terrorist group's membership. Control theory explains the process of joining a terrorist group and indoctrination. Learning theory highlights the importance of education and information-sharing within and between terrorist groups. This is especially important as criminal justice practitioners throughout the criminal justice system are active in the fight against terrorism on American soil.

In most cases, law enforcement (local, state or federal, depending on the country) are the first line of defense against terrorist attacks and the first responders to terroristic events (Hamm, 2007). In many cases, terrorists will be tried in criminal or federal courts, though terrorist trials involving military tribunals receive more press (Shields, Damphousse and Smith, 2006; Damphousse and Shields, 2007). In those criminal cases, terrorists are more likely to act like conventional criminals when they are treated as such and not given any special treatment or designation in the proceedings (Shields, Damphousse and Smith, 2006; Damphousse and Shields, 2007).

However, despite the criminal nature of terrorism and terrorists, the involvement of law enforcement agencies in the deterrence, prevention and response to terrorism and the use of the court system to prosecute terrorists, there are still those who argue that terrorism is separate from crime and terrorists themselves should not be treated as criminals (Etzioni, 2009: Black, 2008). Etzioni (2009) argues that the categorization of terrorists as criminals is incurably flawed: specifically because the role of the criminal justice system in responding to terrorism is to maintain societal security by seeking to prevent future attacks, rather than prosecuting the terrorists after an attack has occurred. He argues that the terrorist, with his or her deep seated beliefs in the cause of his organization, cannot be deterred by arrest or conviction (Etzioni, 2009).

Some support for this view can be found in Black's (2008) assertion that terrorism is a form of social control and selfhelp. Black's (2008) discussion of terrorism is an expansion of earlier arguments that violent crime is moralistic and therefore fits a model of self-help, where individuals engage in criminal behavior to manage conflict (Black, 1983). Black (2008) separates terrorism from crime by highlighting terrorism as being moralistic in nature, and focusing on the war-like and organized tendencies of certain terrorist events and groups that are not generalizable. Black (2008) presents terrorism as something that can be explained through a sociological perspective, looking at terrorism as a form of social control and justice. 
This romantic view of terrorism is out of place with the devastation, disorganization, and lack of concern for human life demonstrated by terrorist groups and individuals employing terroristic means to suit a personal agenda. Rosenfeld (2008) highlights Black's theory of social control as the only theory of terrorism in the discipline of criminology, but is quick to highlight Black's contention that criminology is not suited for a discussion or theoretical examination of terrorism. However, Rosenfeld also highlights the most distinct flaw in Black's theory of terrorism as social control: the decision to ignore "the criminal or predatory component of terrorist violence." (Rosenfeld, 2008: 22). Rosenfeld (2008) does not, however, offer an alternative to Black's theory of terrorism as social control. Hamm (2007) provided a basis for examining terrorism through other criminological theories by examining the pre-event criminal behavior of individual terrorists and terrorist groups.

Using the American Terrorism Survey (a twenty-year database of trial transcripts and court records relating to terrorism cases in the United States, compiled by Smith and Damphousse), Hamm examined trial transcripts related to six terrorist events and the key players involved in those events, which included three international events and three instances of domestic terrorism. Hamm (2007) highlights the individual criminal acts that occurred prior and during each terrorist event. He examines each act committed by the individual terrorists within the group and how these actions drew the attention of law enforcement (Hamm, 2007).

In one case study, Hamm (2007) examines the Aryan Republican Army (ARA), a domestic terrorist group best known for their use of president masks and FBI baseball caps during bank robberies across the Midwestern United States. Long before they decided to form a terrorist organization, the founders of the ARA had criminal records for, among other things, robbery, assault and grand theft auto (Hamm, 2007). The ARA planned to rely on the profits of bank robbery to fund terrorist attacks that fit their anti-government and anti-minority agenda (Hamm, 2007). Due to the flamboyance of their bank robberies and consistent taunting of the FBI, the ARA was caught and tried before they could indulge in their terrorist agenda (Hamm, 2007). However, rumors remain that members of the ARA assisted Oklahoma City Bomber Timothy McVeigh in funding and planning his operation (Hamm, 2007).

Hamm (2007) argues that "by focusing on the broad spectrum of crimes committed by terrorist groups and by acting on solid intelligence, the FBI and other policing agencies may forestall larger conspiracies designed to kill hundreds if not thousands of citizens." (Hamm, 2007; 221). Though Hamm (2007) does demonstrate that terrorists are involved in a wide range of criminal activity, his analysis falls short in its use of routine activity theory and social-learning theory to explain this behavior as proposed in the book's introduction. Though this paper does rely on the same anecdotal examination of terrorism, using historical examples and case studies similar to those presented by Hamm (2007), it examines terrorism in a broader context. Rather than focusing on individual cases, this paper links three types of criminological theories to a variety of terrorist groups and individuals. Examples are drawn from both domestic and international events. Special attention is given to the motivations, ideology, recruitment, training and activity of the various groups discussed.

In order to address how the discipline of criminology is well suited for a discussion or theoretical examination of terrorism, this paper broadly examines three types of criminological theory that can serve as a solid basis for a criminological explanation for terrorism and terrorist action. Each of these theories addresses a different aspect of terrorism. Strain theories help explain the process of terrorist recruitment. Control and learning theories are essential to explaining individual behavior. This includes what factors influence an individual's choice to become a terrorist or the situations and conditions that foster an increase in a terrorist group's membership. Control theory explains the process of joining a terrorist group and indoctrination. Learning theory highlights the importance of education and information-sharing within and between terrorist groups. A variety of examples are provided in order to illustrate the breadth of the reach of criminological theories to explain these acts and organizations.

This paper does not analyze every adaptation of these theories and does not argue that these theories are the only ones among the myriad of criminological and sociological theories that examine crime and criminal behavior that could be applied to the study of terrorism, nor does it argue that these theories are better than others that have been applied to terrorism. It is instead a jumping-off point to introduce criminologists to ways in which they may use these theories to examine terrorism and expand the discussion of terrorism from a criminological perspective. This paper begins with a discussion of terrorism as crime. Each subsequent section examines one of the three categories of theory that will be applied to terrorism. These sections include general discussions of terrorism and terrorists. The paper concludes with a series of case studies linked to each of the theories and theorists discussed.

This paper expands on the use of case studies as a viable option for examining terrorism and fills in the gaps left by previous examinations of terrorism using social learning theory and anomie theory that relied on either general extrapolation or did not link the theory back to the case studies presented. 


\section{Terrorism as Crime}

The diversity of terrorism and terrorists is key to understanding how criminological theories can explain their behavior. Just as anyone can decide to engage in criminal behavior, anyone can become a terrorist. Terrorism encompasses a laundry list of criminal activity; kidnapping, murder, extortion, explosives and other weapon offenses, theft and destruction of public and private property are all crimes committed under the umbrella of terrorism. Specific acts defined as terrorism encompass a range of violent crimes: specifically hijacking, bombings, poisonings and assassinations (Kupperman, Opstal and Williamson, 1982, 25: Ross, 1993). This provides some support for those who believe that, despite differences in motivation, terrorists can be viewed simply as criminals rather than political actors (Turk, 1982).

Before engaging in a terrorist act, terrorists have been known to commit a variety of conventional crimes to support their operations. Theft, counterfeiting and involvement in drug and weapons trafficking are all common criminal behaviors that terrorists use to fund their activities (Hamm, 2007; Fuentes and Kelly, 1999; Dreyfus, 1999; Thoumi, 2002; Carter, 1994; Chabat, 2002; Bantekas, 2003).

The involvement of terrorist groups in the drug trade is well documented, though past research has focused on the multitude of groups engaged in terrorist activity in Latin America. Terrorist organizations such as Shining Path in Peru, the Revolutionary Armed Forces of Colombia (FARC) and Al Qaeda in Afghanistan are involved in the manufacture and distribution of a variety of controlled substances, including opiates, marijuana and cocaine (Bantekas, 2003; Thoumi, 2002; Dreyfus, 1999; ONDCP; 2008).

A clearer picture of terrorism can be developed by examining what makes terrorism similar to other criminal activities and what makes terrorism unique among them. Terrorism is similar to bias or hate crimes, where the crime is considered to have a "symbolic character with messages for the victim, members of the victim's social or actuarial category, other prospective assailants, public officials, and the public at large" (Berk, 1990:339). Terrorism goes beyond the acts themselves to include "the severity of the threat as perceived by the potential victim or victims" (Crenshaw, 1988: 61). Previous examinations of terrorism have addressed these psychological factors by highlighting the fact that terrorism is focused on multiple targets (Berks, 1990: Price, 1977: Combs, 2006). These targets include not only immediate victims, but also groups with similar characteristics to the victims who can identify with the victims and those made aware of the act (not directly impacted) that react according to their sympathies, allegiances and emotions (Price, 1977: 52). Combs (2006) asserts that there are three target audiences for terrorists when they use the media as propaganda: the first is current or future supporters; the second is the general public; and the third is the enemy, or those identified as the potential victims of future attacks (Combs, 2006:139).

Like other types of criminal behavior, terrorism changes over time. Terrorist groups adapt to changes in technology, develop new techniques, learn from failures and respond to changes in foreign and domestic policy (Hamm, 2007). Comparable to street gangs or organized crime organizations, each terrorist group possesses different motives, targets and means (Albini, 2001; Silke, 2008; Hewitt, 2000). Similar to hate crimes, individuals can conduct acts of terrorism with no formal or informal connection to an established group (Albini, 2001; Silke, 2008; Hewitt, 2000).

What makes terrorism unique compared to other crimes is that it employs the resources of its opponents to achieve its ends. Examples include manipulating and exploiting the popular media of a target nation or group (Chermak, 2003) as well as "the technological, cultural, and legal infrastructure of a state against the state's own interests" (Kupperman, Opstal and Williamson, 1982:25, 26). This is the case with much of the terrorism targeting the United States. The People's Committee for Libyan Students, a front organization for Moamar Kaddafi (the charismatic leader of Libya in the 1970s and 80s who provided funds for various terrorist organizations and acts around the world) attempted to increase radicalism in the United States. The People's Committee for Libyan Students sought not only to bring Libyan terrorists to the United States to assassinate political officials and other individuals of interest, but also to inspire civil unrest in the United States (Smith, 1994). The People's Committee for Libyan Students also sponsored domestic American dissident groups to attend pro-Libya conferences and supported protest demonstrations at the White House (Smith, 1994:141,142).

The confusion over what may identify an individual as terrorist, as well as what is and is not terrorism, presents difficulties in applying a singular criminological theory to explain terrorism. However, no single theory explains all crime and no single theory fits every criminal. Because of this, a wealth of theories have been developed to explain certain criminal behaviors and particular types of criminals. Although terrorism is frequently considered to be "different" from criminal behavior, generally terrorism, terrorists and terrorist action can be explained using existing criminological theory. This theoretical examination of terrorism and terrorists begins with strain theory. 


\section{Strain Theory}

Strain theories focus on crime as an individual's reaction to society's problems, norms, cultures, values and goals. Strain theories have been applied to delinquent responses to personal violence and victimization (Baron, 2009: Manasse and Ganem, 2009) and as a predictor of drug use (Lo, Kim and Church, 2008: Carson, Sullivan, Cochran, and Lersch, 2009). Strain theories also highlight differences in race, gender and age in decisions to engage in delinquent behavior (Manasse and Ganem, 2009: Jennings, Piquero, Gover, and Pérez, 2009). Hudson (1999) highlights that terrorists can be drawn from any age group, either gender and from all racial and ethic backgrounds. Some terrorist groups a have a history of recruiting members from a young age, specifically the Liberation Tigers of East Tamil, the Palestinian Liberation Organization (PLO), Basque separatists and, more recently, Islamic extremist groups throughout the Middle East (Hudson, 1999: Ramakrishna, 2006: Pape, 2005: Forrest, 2006). This section builds on the ideas of Hess (2003) and Yacoubian (2006) by providing case studies to support their assertion that strain theory can be used to explain terrorism.

Robert Merton (1938) asserted that certain goals and values, such as monetary success, are highly prized by society. However, there is differential access to legitimate opportunities for achieving these goals depending on social class, education, gender and ethnicity. In Merton's theory, individuals are rational actors who choose different behaviors for the situations in which they find themselves in order to serve their best personal interests and achieve their goals (Merton, 1938). Individuals who have little or no access to legitimate opportunities still seek these goals and turn to illegitimate opportunities, such as crime, in order to achieve them (Merton, 1938). As individuals are blocked from a desired goal, they respond in a variety of ways: some conform or ritualize their behavior; others retreat from society; and still others innovate or rebel against the conventions of society. Criminological interest has often focused on the innovator response; however, with regard to terrorism, rebellion is the response of interest.

Merton's theory was specifically meant to apply to society in the United States, since the desires of individuals are the result of cultural influence (Passas, 1995). However, the core elements of the theory have implications for the study of terrorism throughout the world. Groups that identify the United States and other Western nations as targets often believe that the norms and values of these nations are undermining their organizational or traditional beliefs and culture. Individuals become terrorists or join terrorist groups with a purpose. Inspired by social, cultural and religious ideas such as Jihad[1], Fatwa[2] and Istishhad[3] or Fedayeen[4] (as expressed by both legitimate and terrorist authority figures), young recruits to Hezbollah believe that they are preserving their culture and assisting in the creation of "a future Lebanon that will regain stability through Islamic law and justice and embark upon the redeeming struggle against those who banish Islam from this Earth" (Kramer, 1998: 132).

Agnew's (1992) general theory of strain was proposed to explain middle class delinquency. Agnew (1992) argued that goals are ideals and not realities. From this standpoint, whether or not an individual could achieve these goals or what opportunities were available was not a source of frustration or anger; the way in which an individual is treated has more influence on their future behavior (Agnew, 1992). An individual engages in delinquent behavior as a result of a threestep process. First is the actual or anticipated failure to achieve a goal. The second is the actual or anticipated removal of positively valued stimuli. The third is the occurrence of strain with the application of actual or anticipated negatively valued stimuli, such as punishment (Agnew, 1992). Individuals engage in delinquent behavior when they respond to strain with negative emotion coupled with familial or social pressure to engage in corrective action to reduce or resolve strain. In engaging in delinquent behavior, individuals are not only attempting to achieve goals but also avoid pain, sometimes engaging in delinquent behavior as a technique to avoid situations that they identify as painful (Agnew, 1992).

As an explanation for terrorist recruitment, the distinction Agnew makes with respect to the applicability of his theory to members of the middle class is still important. Terrorist group recruits can be drawn from every strata of society: not only the poor and destitute, but also the well-educated, the upwardly mobile, and the well-off (Hudson, 1999). Previous studies of terrorism, focusing predominantly in Europe and the Middle East, have identified approximately 75\% of terrorist group members as having some level of higher education (Russell and Miller, 1977). Many terrorists have legitimate professions that help them to avoid detection, as in the cases of members of sleeper cells (Hudson, 1999). For these middle-class or upper-class terrorists, the goals of the terrorist group supersede their standing in the community (Russell and Miller, 1977: Hudson, 1999). The failed goal is the achievement of the terrorist group's agenda through legitimate means: though they may never actually attempt to achieve these goals through legitimate means, they believe that no legitimate means of achieving those goals exist. Since the goal is considered more important than life, wealth or status, these trappings of their position lose their appeal and provide no positive stimuli for continuing their careers and ignoring the terrorist agenda. 
As the agenda of a terrorist group often calls for social and/or political changes, the lack of these changes and the middle-class terrorist's continued life under the rules and norms that are not acceptable to the terrorist group acts as the negative stimuli to continue their involvement in the terrorist group until the agenda is met.

Albert Cohen sought to explain how it is that some young boys come to engage in delinquent behavior either individually or as members of youth gangs (Cohen, 1955). Cohen theorized that status frustration results from individuals from lower classes being held to upper class standards for respect or recognition of their self-worth. These individuals react by forming delinquent subcultures. These subcultures redefine social values and individuals dismiss, disregard, and discredit the knowledge and values of other groups (Cohen, 1955). This process is further advanced by the ridicule of authority figures or other proponents of opposing or rejected knowledge and values. Individuals respond to social and situational strain as a group, creating new norms, values and goals for their group which are at odds with middle-class goals (Cohen, 1955). Membership in a deviant subculture becomes the pinnacle of status for the delinquents, similar to the way that membership in a terrorist group becomes a status symbol for individuals raised in refugee camps or other areas in which terrorist ideologies are prevalent. These areas are often ones in which there are very few opportunities for young people. Extreme poverty is rampant and aid is limited or nonexistent. Young people faced with these situations often find membership in a local terrorist organization as the only way to gain status and respect in their community (Hudson, 1999).

Hamm expanded upon this by theorizing that bonds can be created between individuals through a "common hatred of social out groups." (Hamm, 2004: 327). According to Hamm, terrorist, militia and hate groups in the United States are formed around a common factor: "an intense collective hatred for the federal government" (Hamm, 2004: 334). This idea of a collective hatred, prejudice or bigotry is not limited to domestic groups in the United States. It can also be seen among groups in the Middle East, especially among Islamic militant youth targeting the United States, nonMuslims and Jews (Ramakrishna, 2006).

Though there has been some debate as to whether or not Cloward and Ohlin are strain theorists (see Cullen, 1988), Cloward and Ohlin will be discussed in this section due to similarities to Cohen's theory: specifically, the development of delinquent subcultures. Cloward and Ohlin's (1960) theory of differential opportunity examines how individuals respond to strain with innovation. However, just as Merton theorized that legitimate opportunities are unequally or unevenly distributed, Cloward and Ohlin identified illegitimate opportunities to resolve strain as subject to the same distribution. The form that the innovation takes is determined by the opportunities for innovation that are available (Cloward and Ohlin, 1960). The key element of Cloward and Ohlin's theory is that, before a delinquent subculture forms or an individual engages in deviant behavior, said individual experiences some level of alienation from accepted society (Cloward and Ohlin, 1960). This alienation leads the individual to seek out similar individuals. During this search, individuals increasingly reject any commitment to the social norms and values of legitimate society. They also reject the opportunities presented by society for the achievement of goals (Cloward and Ohlin, 1960). Strain theory can apply both to individual action and group involvement and recruitment.

\section{Control Theory}

Control theories are essential for understanding an individual's decision to become a terrorist or join a terrorist group, as well as the decision to remain. Control theories have been used to explain extreme drinking behaviors (Costello, Anderson, and Stein, 2006), marijuana use and desistance (Maume, Ousey, and Beaver, 2005), as well as gang involvement and school violence (Koffman, Ray, Berg, Covington, Albarran, and Vasquez, 2009: Melde and Esbensen, 2009: Hall, 2009: Felix, Furlong and Austin, 2009). Due to control theory's exploration of the bonds individuals form to groups of likeminded individuals, it is ideal for an examination of terrorism. Although terrorist actions can be perpetrated by lone wolf terrorists with no definitive link to any known organization, much of terrorism is perpetrated by individuals who are members of an identifiable group (Hudson, 1999: Hamm, 2007).

Travis Hirshi (1969) theorized that social bonds are paramount to understanding whether or not an individual will engage in delinquency. These social bonds include attachment to one's peers and family, commitment to conventional behavior, involvement in conventional activities and belief in the moral validity of such conventions. Attachment is represented by the value an individual places on the opinions and expectations of those he or she cares about, such as friends and family. Commitment includes how an individual accepts and lives up to the expectations of society, something that would be endangered by involvement in criminal or delinquent behaviors (Hirshi, 1969). Involvement in conventional activities is included in Hirshi's theory as a time-use element: the more time an individual spends on conventional activities, the less time such individuals have to engage in crime. Belief refers to the conventional norms and values of society and how much validity the individual feels those conventional norms and values have in his or her life. 
Hirshi's theory is important to the terrorism discourse in that it can identify how an individual becomes ensconced in a terrorist group and lifestyle. Individuals who become involved in terrorist groups usually start out as sympathizers, or share common ideological beliefs and a disenchantment with legitimate political or social processes (Hudson, 1999: 36, 37). The environment in which terrorism thrives also assists in the recruitment of new members (Rapoport, 1998; Ramakrishna, 2006). This is especially true in refugee camps where Wahabist and other extremist schools are established nearby (Kellen, 1998; Ferracuti, 1998). These schools serve as the only potential education for many young people, most of whom lost everything before entering into the camps (Kellen, 1998; Ferracuti, 1998; Rapoport, 1998; Hudson, 1999; Ramakrishna, 2006). In the absence of other social institutions, social bonds are formed and strengthened to the terrorist organization. Once an individual joins the terrorist group, most connections to the outside world are cut off, replaced by ties to other members of the group and its alliances. The new terrorist accepts the norms and values of the organization as paramount to any outside viewpoint (Hudson, 1999). The terrorist's activities become limited to those that further the cause, such as studying doctrine, training or preparation for a terroristic event (Forrest, 2006: Weinman, 2006: Combs, 2006: Hudson, 1999: Hamm, 2007).

Walter Reckless (1961) put forth containment theory, which posits that individuals are influenced to engage in delinquent activity by pushes from the environment and pulls from the peer group. At the same time, an individual is prevented from engaging in delinquency by his adherence to the wishes of authority figures. He is further contained by his own sense of guilt and a positive self-concept. This self-concept is developed early in life and subject to change based on life experience. A positive self-concept is a buffer between the individual and the wishes of those around him (Reckless, 1961). This buffer is the individual's greatest defense against succumbing to delinquency and criminal activity (Reckless, 1961).

This theory is applicable to terrorist recruitment in impoverished areas, refugee camps and cities where terrorist activity is prevalent. In these locations, although parents and guardians may not want their children involved in terrorist activities, their peers are often recruited and provide encouragement to leave the destitution of their situation for the "glory" of involvement with the local terrorist organization (Kellen, 1998; Ferracuti, 1998; Rapoport, 1998; Hudson, 1999; Ramakrishna, 2006). For these young people, the only positive self-concept that can be found in these situations is in the terrorist organization (Hudson, 1999: Ramakrishna, 2006). William Julius Wilson's (1987) examination of the inner city American ghetto provides an analogy to the conditions in impoverished areas around the world where terrorist activity flourishes. Wilson (1987) documents the exodus of middle class families from inner-city communities, which results in a number of consequences, including increased crime and concentrated poverty. Wilson (1987) describes a process of cultural adaptation in these communities that comes about as a consequence of social isolation. The "underclass" that remains in the community is characterized by a lack of middle-class role models, resulting in the adoption of criminal or antisocial ideals (Wilson, 1987). In refugee camps, isolated young men and women who would not have engaged in terrorist activity in their home communities begin to see the terrorist activity and membership in a terrorist organization as accepted and desirable behavior in the absence of other alternatives.

Jackson Toby (1957) identifies a key element of the decision of youth to become part of a terrorist organization: the idea that "for those with social honor, disgrace is a powerful sanction" (Toby, 1957; 16). Toby argues that individuals must have some level of investment in the conventional norms and values of their community, a stake in conformity (Toby, 1957). He also argues that young people engage in delinquency due to a lack of guardianship. The multitude of responsibilities and problems facing parents and responsible elders results in a lack of time or attention to the activities of the young (Toby, 1957). In many communities, and especially in refugee camps, a young person engaging in terrorist acts or joining a terrorist group can be seen as experiencing a lack of or limited social vigilance. Families are separated either through death or refugee camp regulations. This means that the parents are not watching out for their children and do not hold the same influence over their decisions as they may have in their home community. The values and norms of their home community are also superseded by the values and norms of the refugee camp. The original stake that young people had in their community and its values is eroded and replaced by the norms and values of the refugee camp, where becoming part of a terrorist organization may be seen as a way of regaining status and honor for the family or for oneself.

\section{Learning Theory}

Social learning theories are a collection of broad theories examining the communal, cultural and solitary elements that result in the acquisition of traditional and deviant or criminal skills and behaviors. These theories have been applied to generational trends in domestic violence and interpersonal abuse (Ireland and Smith, 2009: Josephson and Proulx, 2008) as well as the role of friends, guardians and family members in an individual's choice to become delinquent (Craine, Tanaka, Nishina, and Conger, 2009: Baerveldt, Völker, and Van Rossem, 2008: Ryan, Testa, and Fuhua, 2008). 
In regard to terrorism, these theories can be used to examine how a certain individual or group of individuals gained the skills and convictions that resulted in their actual or attempted terrorist behavior, either through formal recruitment and training at terrorist training camps (Forrest, 2006) or through online recruitment, informal associations or personal study on the Internet (Weimann, 2006). This section builds on the extrapolation of Ruby (2002) and case studies presented by Hamm and Van de Voorde, (2005) and Hamm (2007) that argued for the use of these theories but did not link the theories back to their case studies.

Edwin Sutherland (1947) asserted in his theory of differential association that criminal behavior is learned. Individuals accrue a series of definitions favorable to deviance through a process of interaction and communication with other deviants over a period of time, during which those definitions are frequently and intensely reinforced. The key elements are the content of what is learned and the process by which the individual learns it. Individuals may learn in formal school settings or in more intimate groups of peers, which may influence the context and situation in which the definitions are acquired and internalized. Sutherland highlights that, beyond learning how to engage in criminal behavior, they also adopt a sense of why they are involved in this behavior and motives for their actions. Included with these motives are appropriate rationalizations and attitudes with which to assuage guilt and fear, as well as respond to sanction and threats of punishment (Sutherland, 1947).

Burgess and Akers (1966) expand upon Sutherland's ideas by expounding that learning is based on operant conditioning in both social and nonsocial situations. In these situations, the behavior of interest is reinforced and other behaviors are discouraged and ridiculed. The primary concern is the frequent availability of a major source of effective reinforcement. The deviant behavior must be effectively and continuously reinforced by the individual's reference group: the deviant peers with whom the individual has the closest connection or bond. Training camps and schools are set up by terrorist organizations for instruction in the beliefs and values of the organization running the training (Forest, 2006). These camps also provide hands-on lessons in how to use a variety of weapons, tactics for kidnapping and combat situations and the creation of explosive devices, deliberately creating opportunities for interaction with likeminded others and for operant conditioning (Forest, 2006).

Daniel Glaser (1978) adapts the concepts of differential association to his theory of differential identification. Glaser proposed that an individual does not need to meet or have contact with other deviant individuals to develop a deviant belief system or engage in a particular behavior.; he need only adopt that person or group as a reference point (Glaser, 1978). This is an expansion of Burgess and Akers' (1966) concept of a reference group. This process can occur through identification with media portrayals of real individuals, or even fictional characters in books or movies. More recently, changes in technology have expanded upon Sutherland's theory of differential association, as well as Burgess and Akers' reference group. Warr (2002) expands these theories by looking at virtual groups where, unlike Glaser's differential identification, an individual maintains contact and interaction with a group of individuals with whom he will never meet but has formed strong ties through the Internet, such as in chat rooms, multi-player computer games or other virtual interaction.

This theory can be applied to the use of the media and Internet in propaganda, recruitment, communication and providing information on tactics, in addition to straightforward indoctrination (Weinman, 2006: Combs, 2006). Propaganda is not bound by time, as illustrated by the Neo-Nazi movement's idealization of Adolf Hitler and the tenets of German National Socialism (George and Wilcox, 1996; Elliott, 1998). Neo-Nazis, some skinhead groups and other extremist groups (predominately in the United States and Western Europe) rally around the ideas presented by Hitler in his writings and speeches; they glorify him and his plans for the Third Reich (George and Wilcox, 1996; Elliott, 1998). These extremists often emulate the activities, dress and gestures of their Nazi predecessors and actively promote the goals of Hitler and his party (George and Wilcox, 1996; Elliott, 1998). Propaganda can influence acts of violence and escalation long after the organization that originated the information has disbanded (Torres, Jordan and Horsburgh, 2006; Garrison, 2004).

Among more traditional terrorist groups, propaganda permeates almost every social setting; in some areas like Lebanon and Palestine, the State produces the propaganda and it is heard on the radio and seen on television, as well as in books and other print media (Torres, Jordan and Horsburgh, 2006; Garrison, 2004). Propaganda materials produced by terrorist organizations in Chechnya and Iraq (Forest, 2006:90, 93) are used to glorify the role of terrorists. This belief that being a terrorist is glorious or heroic increases recruitment not only in the Middle East but also in the United States and Great Britain (Hudson, 1999; Forest, 2006; Weinman, 2006; Torres, Jordan and Horsburgh, 2006; Garrison, 2004). Often the individual recruited through their responses to propaganda are those "who feel alienated from society and have a grievance or regard themselves as victims of injustice" (Hudson, 1999:77). The use of propaganda within or between groups with similar views can influence the escalation towards terrorism (Weimann, 2006; Silke, 2008; Torres, Jordan and Horsburgh, 2006; Garrison, 2004). 
Propaganda, especially that depicting violent acts perpetrated by members of a group, may be seen as a call to perpetrate similar acts by members of the same group, another faction of the same group, individuals working alone or members of groups with similar ideologies (Torres, Jordan and Horsburgh, 2006; Garrison, 2004).

Sykes and Matza's (1957) theory of neutralization argues that there exists a series of subterranean values within conventional society within which legal codes are seen as inconsistent and vulnerable. This means that the legal code is not consistently upheld, punishments vary or are nonexistent, and the individuals who observe this are more likely to dismiss these legal codes. The adoption of subterranean values can result from prejudicial treatment or the informal acceptance of some rule-breaking by authority figures (Sykes and Matza, 1957). Legal codes that are applied in an inconsistent or prejudicial fashion become vulnerable and lose their influence over the general population and especially those who are interested in engaging in crime (Sykes and Matza, 1957). If excuses for illegal behavior are accepted by authority figures (i.e. the police or parents) and an individual is not punished for the behavior, the law becomes neutralized, decreasing an individual's belief that he should adhere to any established laws (Sykes and Matza, 1957). Neutralization can occur at any time before, during or after a criminal event and includes: the denial of responsibility, denial of injury and/or denial of the victim, condemnation of the condemner and/or an appeal to higher loyalties (Sykes and Matza, 1957). The decision to employ suicide bombings illustrates the concept of neutralization. Even though martyrdom at the hands of an enemy is celebrated, suicide is shunned by Islam (Merari, 1998). Suicide bombings are justified by some terrorist organizations based on the belief that "no other means remained for Muslims to confront the massive power commanded by the United States and Israel" (Kramer, 1998:144).

\section{Applying Theory: Case Studies of Terrorism}

Each of the theories discussed can be applied to terrorism. The following sections provide case studies to show how these theories can be applied to terrorism. The first section below examines strain theory as it applies to terrorism.

\section{Strain Theory}

The Abu Sayaaf illustrates the rebellion response to blocked access to legitimate opportunity in the classic Mertonian formulation. Formed in 1991, the Abu Sayaaf originated in Afghanistan during the 1980s war against the Soviet Army, when its leader, Abdurajak Janajali, was exposed to Wahhabism (an extreme form of Islam considered very conservative and intolerant by most moderate Muslims) during his volunteer service there (Dulin, 2006). The Abu Sayaaf has a membership of approximately 1,200 men (Desker and Ramakrishna, 2002). The group serves as a supplier of weapons, explosives and drugs for other terrorist organizations, such as Al Qaeda and other Islamic groups (Dulin, 2006). The group claims that their involvement in terrorist action, specifically kidnapping and extortion, is an attempt to establish an independent state for the Islamic minority of the Philippines, though this purely religious motivation has been disputed in the past (Dulin, 2006; Gershman, 2002). The Abu Sayaaf does not believe that they can establish an independent Islamic state through any legitimate political process. Since they have rejected the use of legitimate political means for establishing their independent Islamic state, they have opted for violent and terroristic means to show the ruling majority and the international community their strength and conviction to this goal (Dulin, 2006; Gershman, 2002).

For lone wolf terrorists such as "Unabomber" Ted Kaczynski and Timothy McVeigh, the raw materials and information necessary for them to carry out their own terrorist action was available and they acted with limited or no assistance. McVeigh pointed out a perceived faltering in the system of checks and balances in the American legal system, as well as an inability to change what he viewed as abuses of the system through legitimate peaceful protest and use of the media, as part of his motivation to bomb the Murrah Federal Building (McVeigh, 2001). The Unabomber, Ted Kasczinski, addressed a desire to destroy technology in order to save society. The Unabomber's Manifesto begins with a declaration that "the Industrial Revolution and its consequences have been a disaster for the human race" (Kaczynski). His views and subsequent actions present Kasczinski as an example of Merton's rebel response, especially in light of his intelligence and educational background, which allowed him access to legitimate opportunities.

Another example of a terrorist group that illustrates the rebellion and innovation responses of Merton's theory is the Narodniki: an early anti-tsarist group active in Russia during the late nineteenth and early twentieth centuries. Nearly all Narodniki members had backgrounds in medicine and law; most were college educated (Engel and Rosenthal, 1975; Figner, 1927). For the members of the Narodniki, terrorism and revolution were preferred to the lives of doctors or lawyers due to their belief in their cause and disinterest in maintaining a position of prestige or wealth without the power to make the changes they wished to see in their homeland (Figner, 1927; Engel and Rosenthal, 1975). 
They identified a disparity in the distribution of wealth, power and prestige between the tsarist government and the general population, and therefore wanted to either overthrow or kill the tsar, then either force his successor to improve conditions for the general population (especially the serfs) or to abdicate in favor of a new representative or Marxist government (Figner, 1927; Engel and Rosenthal, 1975). Their tactics included assassinations and bombings in furtherance of their goal of liberating Russia from the control of the tsar, allowing for a redistribution of wealth, increased opportunities and the end of serfdom (Engel and Rosenthal, 1975; Figner, 1927). The Narodniki's view that they did not have access to legitimate opportunities for achieving their goal of greater equality between the classes in Tsarist Russia is exemplified by their response to the assassination of President McKinley in 1901 (Figner, 1927). After the assassination, the Narodniki sent an open letter to the American public rebuking the assassins (Figner, 1927). The letter stated that there was no need for an anarchist revolution in the United States, as the citizens of the United States already had everything the Narodniki were fighting for (Figner, 1927).

The Weather Underground broke away from the less-radical Students for a Democratic Society (SDS) in 1969 as a response to the latter's desire to avoid violent protest (Jacobs, 1997). Frustrated by the lack of progress on part of the SDS over the course of approximately a year (January, 1968-June 1969), the Weather Underground saw peaceful protest as incapable of achieving their goals. These goals included preventing ecological ruin by American business and the destruction of U.S. imperialism, especially its ability to wage war and exploit the people (Jacobs, 1997; Varon, 2004). The Weather Underground believed that the high costs of fuel and food were illustrations of the evils of American imperialism and hoped that their revolution would help liberate exploited people and nations (Jacobs, 1997; Varon, 2004). As police and local officials responded to all forms of protest with increasing violence, the Weather Underground and other organizations with similar goals of revolution in the United States became unwilling to work with what they saw as a failed system (Jacobs, 1997; Varon, 2004). Instead, they opted to respond with planned violence, riots, bombings and urban guerilla warfare (Jacobs, 1997: Varon, 2004).

\section{Control Theory}

The experience of the so-called "Baader-Meinhof gang[5]", or Red Army Faction of West Germany, illustrates the applicability of control theory to the explanation of terrorist groups and activity. andreas Baader was an arsonist with a long history as a juvenile delinquent, a propensity towards violence and explosives and leftist leanings (Kellen, 1998: Varon, 2004). The Red Army Faction, or Rote Armee Fraktion, was founded in May of 1970 after liberating Baader from police custody at the library of the Institute for Social Issues outside of Berlin (Varon, 2004). The group was composed mostly of disaffected young people lacking strong bonds to family or other conventional institutions (Kellen, 1998). The group took the name Red Army Faction (RAF) in order to draw parallels to the Soviet Red Army, an organization feared and hated by most Germans and one of the victors over the German people in World War II; the acronym also brought to mind another victor from the war, England's Royal Air Force (Varon, 2004). Active in anarchist and communist circles, their primary goal was to establish an armed resistance in West Germany and West Berlin with the hopes of unifying Germany under a single communist system (Varon, 2004). The RAF garnered support from sympathizers throughout West Germany: mostly adolescents, intellectuals and students. The German media and government invoked a frenzy of suspicion when they sought to find and arrest all sympathizers stating that "[t]he sympathizer is an accomplice...no better than the murderer" (Varon, 2004: 254).

The young people who comprised the membership of the RAF "never belonged anywhere and had no success, no money and no power until suddenly they became players on the world stage, dealing with prime ministers and commanding headlines" (Kellen, 1998:53). Such a change in status and the accompanying feelings of self-worth, power and importance could easily strengthen bonds to a terrorist group. This example highlights how Hirshi's theory can be applied to terrorism: bonds are formed to the terrorist group as well as to the cause for which the group is fighting, making all outside influences insignificant.

Once these organizations have recruited new members and the decision has been made by those recruits to actively engage in terrorism, the process of becoming a terrorist begins. The applicability of control theory to the explanation of terrorism can also be illustrated by the case of Carlos the Jackal. Carlos was a terrorist-for-hire, used by various Middle Eastern and Soviet regimes throughout his career for bombings and murder (Follain, 1998). Born Ilich Ramirez Sanchez in Caracas, Venezuela in 1949, his father named him in honor of his revolutionary hero, Vladimir Ilyich Lenin. Along with other members of the Jackal's extended family, his father began to indoctrinate him in revolutionary ideology at a young age (Follain, 1998). Throughout his life, as a result of the choices made by his father for his early education and his own subsequent choices to pursue revolutionary ideals, Carlos was isolated from conventional societal institutions. Instead, he sought out radical groups and flaunted disobedience to school and government policies (Follain, 1998). 
He attended radical schools at his father's behest and joined the outlawed Venezuelan Communist Youth as a teenager. He later attended university in Moscow and from there established contacts with Palestinians, resulting in his training with the Popular Front for the Liberation of Palestine (Follain, 1998).

Even though Carlos the Jackal was idealized by his employers, his enemies and the popular media as a "born terrorist" (Follain, 1998), his own history details that an individual who decides to become a terrorist does not naturally possess an innate understanding of how to manufacture explosives or participate in a hijacking. These skills must be learned. In order to understand this element of terrorism, it is vital to examine learning theory.

\section{Learning Theory}

An individual who wishes to be a terrorist must learn to be a terrorist. Whether he is taught formally in a training camp or self-taught through Internet resources and personal trial and error, there are skills and techniques that must be learned. Being involved in terrorist organizations and activities is in many cases a psychological process of indoctrination (Bandura, 1998). Trainees are encouraged to dehumanize victims and targets, morally justify their behavior based on ideology and displace the responsibility for their actions through obedience to the commands of their leaders within the organization (Bandura, 1998). Formal terrorist training camps and informal or formal connections made over the Internet allow terrorist groups to share information and training techniques across ideologies in order to manipulate events and disrupt enemy states (Kupperman, Opstal and Williamson, 1982; Forest, 2006).

The trend of sharing tactics with other terrorist or revolutionary groups was started by the Irish Republican Army in the 1960s and 70s. As they successfully engaged in terrorist activity, they shared their knowledge through training: not only in their own training camps, but in those of other organizations despite ideological and religious differences (Dulin, 2006; Forest, 2006). Any number of terrorist groups could attend training at these camps at the same time. This means that Islamic groups may be training with groups adhering to Christian theology or groups that advocate the abolishment of all religions (Dulin, 2006; Forest, 2006). While American and other military forces have endeavored to destroy formal terrorist training camps, they still remain in operation (Forrest, 2006). However, the information has become increasingly available on the Internet for those who are unable to access such formal training facilities (Forrest, 2006: Weinman, 2006: Combs, 2006).

An example of how this use of propaganda can be related to Glaser's differential association theory is the case of the terrorists referred to as the Fort Dix Six. These individuals, all of whom had lived in the United States since they were very young and had no active contact with any known terrorist organization, plotted to engage in a terrorist attack against Fort Dix military base in New Jersey (Coughlin, 2007; Ripley, 2007). Only two had relatives who had interest in Muslim extremism and jihad (Ripley, 2007). FBI informants who infiltrated the group reported that members of the group frequently watched jihadist propaganda from Iraq and Afghanistan, avidly consuming the videos (Coughlin, 2007; Ripley, 2007). Specifically, they were fascinated by Juba the Sniper, best known for his Baghdad Sniper DVDs, in which he records sniper-style attacks on American soldiers in Iraq. The would-be terrorists reportedly hoped to emulate him in their attack on Fort Dix (Coughlin, 2007; Ripley, 2007).

\section{A Diagram of How Criminological Theories and Terrorism Intersect}

The diagram below shows the elements of terrorism that have been discussed in the case study and theory sections of this paper.

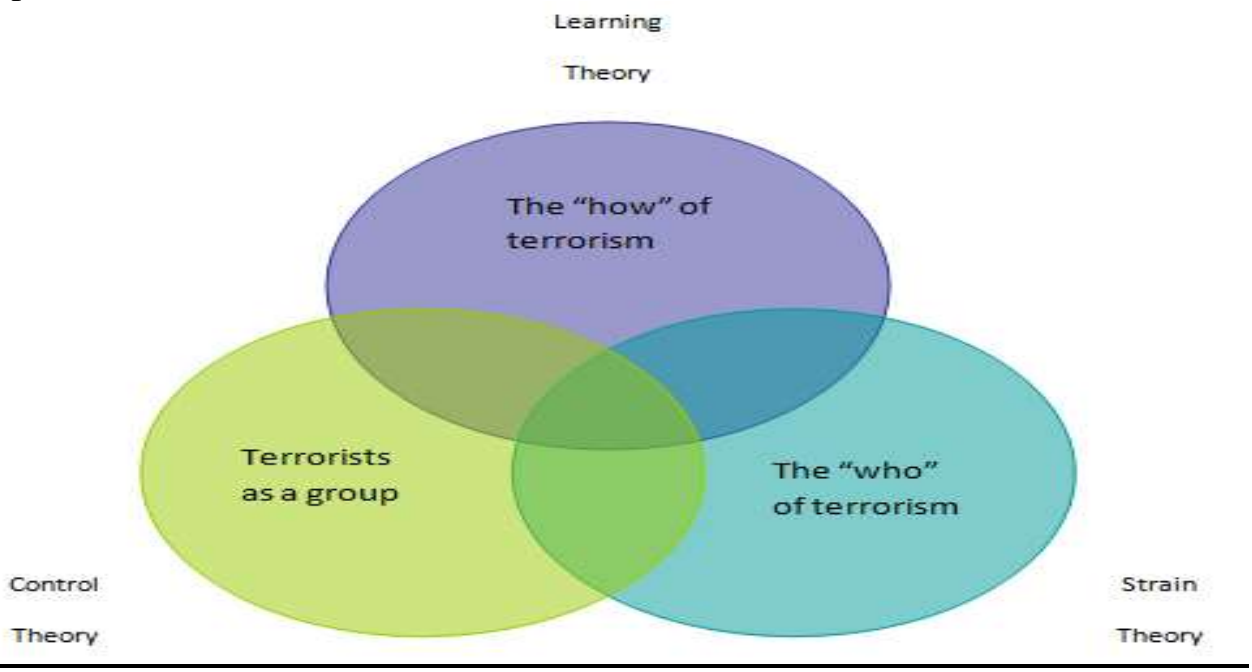


The circle at the apex represents learning theories, which can be applied to the "how" of terrorism. The process of becoming a terrorist, learning the belief system of the terrorist group and how to construct a bomb or conduct a hijacking is an intense process with formal and informal teachers, either in training camps or through use of Internet resources. Terrorism may be something that someone is drawn to from an early age, but the skills of a terrorist must be learned.

The circle of the right represents strain theories, which can be applied to the "who" of terrorism. Terrorist groups need members, and in order to achieve their goals, those members must be drawn from every aspect and strata of society. Terrorism cannot take place without terrorists, so the "who" of terrorism is equally as important as the "how".

The circle on the right represents control theories, which can be applied to terrorists as a group. While lone wolves are a threat in most countries, terrorists are inclined to form groups, either formally in the physical world or informally in the virtual one.

Each of these circles is shown as overlapping with the others for good reason. While the case studies presented in this paper examine the different aspects of terrorism and theory separately in order to present a clearer argument for the use of these theories, each one can be seen as overlapping with the others because terrorism is a complex entity, and each of these theories is attempting to explain one part of it.

The first overlap of interest is that between learning theories and strain theories. The "who" and the "how" of terrorism are intricately connected, especially when terrorist groups are seeking to recruit specific individuals from different professions or with particular skills. Once terrorists are recruited, or an individual makes the decision to be a terrorist, they must learn how to be a terrorist. Without the proper training, a recruit or someone interested in terrorism is a neophyte and not of much assistance to a terrorist group.

The second overlap of interest is that between learning and control theories: the "how" and terrorists as a cohesive formed unit or group. Part of the learning process is learning the norms and goals of the group. The training of terrorists can serve to further reinforce their bonds to the other members of the group through shared experience and indoctrination. This assures that members of the same group, whether or not they received their training at the same time, have that same camaraderie.

The third overlap of interest is that between control theories and strain theories: the "who" and the terrorists as a group. The individuals recruited by terrorist groups or drawn to terrorism are the building blocks of a terrorist group. As strain theory explains how these individuals come from a diverse background, control theories explain how these diverse backgrounds come together and work together towards the common goal of the group.

Combining all three theories together in the center of the diagram shows where the "who" and the "how" fold into the group dynamic. Scholars who seek to use these theories to explain these simplified elements of terrorism should be mindful of the interplay between the theories, but should not be distracted by the larger picture. Scholars interested in the "who" of terrorism should focus on strain theory. Those interested in the "how" of terrorism will find a solid theoretical basis in learning theories, and those interested in terrorist groups ought to examine those groups through the tenets of control theory.

\section{Conclusion}

Within the field of criminology and criminal justice, terrorism has historically been relegated to a separate category, distinct from other types of criminal behavior. This article argues that this approach is flawed and that criminological theories can explain terrorism and terrorist activity. Terrorism is not so different from the crimes that criminologists currently study. Murder, theft, kidnapping, weapons violations, destruction of private and public property are all encompassed by terrorism. Terrorists are criminals and terrorist organizations are similar to other criminal groups. Because of this, a criminological approach to terrorism can assist in the development of anti-terrorism and homeland security policy, as these theories identify root causes of terrorism. Criminologists have a long history of operationalizing and empirically testing theories designed to explain criminal behavior. These same theories can offer great insight into terrorist behavior and terrorism in general. In the same way, innovators in criminology have taken the key elements of the theories discussed herein and applied them to emergent trends in crime and violence as new advances in crime or in the experiences of criminal justice practitioners have drawn their interest (e.g.Passas, 1990; Bierne 1995, 1997, 1999).

Hudson (1999) advocates the examination of each terrorist group within the norms of "its own cultural, economic, political and social context in order to better understand the motivations of its individual members and leaders and their particular ideologies" (Hudson, 1999:98). This would require the use of ethnographic criminology. Such studies would be a very dangerous undertaking, but not impossible. 
However, the similarities between terrorists and terrorist groups and other criminal enterprises, such as organized crime or street gangs, make it likely that criminologists are better prepared for such research than other disciplines. Terrorist groups are, for the most part, as secretive and difficult to access as other criminal groups that ethnographic criminologists have previously studied, as demonstrated by Hamm's (1994) ethnographic and empirical examination of racist skinheads in the United States.

An understanding of which criminological theories can be used to explain different aspects of terrorism is a key starting point for a more in-depth criminological examination of this phenomenon. Strain theories apply to terrorism and recruitment. Understanding why individuals join terrorist groups or become active in terrorism can be framed by control theories. As illustrated earlier in this paper, an individual's involvement with a terrorist group can change his status, and the accompanying feelings of self-worth, power and importance could easily strengthen bonds to a terrorist group and weaken conventional bonds. Studies relying on strain theory and control theory to explain terrorism should be considered in developing anti-terrorism policies, especially with regard to the assistance given to foreign nations with well-established or emerging terrorist groups. In areas where refugee camps and impoverished slums are recruiting grounds for terrorist organizations, closer examination of terrorism according to these theories can assist in developing intervention programs to provide educational and social opportunities for young people who would otherwise become terrorists. Learning theories address the formal and informal processes of becoming terrorists and engaging in terrorism. This is in part due to the presence of both formal and informal terrorist training camps and schools, as well as the prevalence of information-sharing through the Internet, both between members of terrorist groups and those individuals who seek to become involved in terrorist activity without membership in an organization.

This paper has provided a jumping off point for criminologists interested in studying terrorism. Additionally, the theories and examples provided should be seen as a guide for criminologists attempting to expand the discussion of terrorism within the criminological discipline. The theories and examples discussed are only a sampling of the uses of criminological theory that may be relevant to the terrorism discourse. Future research could focus on conflict theories, which may also help to explain the social and political processes that give rise to terrorist organizations. For example, groups with a revolutionary or anarchist ideology, such as neo-Nazi and neo-Fascist groups in Germany and Italy and communist and revolutionary movements in Latin America, dismiss the idea of entering legitimate political discourse in favor of violence to express their views and gain power (Gurr, 1998:91, Sprinzak, 1998:84). Ideological political terrorism is fueled by the mindset of its participants, a perceived or imagined "war with authorities and expend themselves in the struggle to win it" (Sprinzak, 1998:85). An examination of such groups would provide a myriad of case studies to support the use of conflict theories in the discussion of terrorism and would provide an interesting basis for future research.

Each theory that has been discussed provides a frame of reference for explaining terrorism, terrorists and terrorist groups. The use and empirical testing of criminological theories in the examination of terrorism, terrorists and terrorist groups can only stand to expand the discourse and provide potential insight into this phenomenon.

\section{References}

Agnew, R.S. (1992). Foundation for a General Strain Theory of Crime and Delinquency. Criminology 30, 47-87.

Albini, J.L. (2001). Dealing with the modern terrorist: the need for changes in strategies and tactics in the new war on terrorism Criminal Justice Policy Review 12, 255-281.

Anderson, S.K. and Spagnolo, P.N. (2007). The Achille Lauro Hijacking. In Forest, J.J.F ed. Countering Terrorism and Insurgency in the $21^{s t}$ Century: International Perspectives: Lessons from the Fight Against Terrorism, Volume 3. (pp. 52-69). London: Praeger Security International.

Baerveldt, C., Völker, B., and Van Rossem, R. (2008). Revisiting Selection and Influence: An Inquiry into the Friendship Networks of High School Students and Their Association with Delinquency. Canadian Journal of Criminology \& Criminal Justice, 50(5), 559-587.

Bandura, A. (1998). Mechanisms of moral disengagement. In Reich, W ed. Origins of Terrorism: Psychologies, ideologies, theologies, states of mind. (pp. 161-191). Washington D.C.: Woodrow Wilson Center Press.

Bantekas, I. (2003). The International Law of Terrorist Financing. The American Journal of International Law 97, 315-333

Baron, S. (2009). Street youths' violent responses to violent personal, vicarious, and anticipated strain. Journal of Criminal Justice, 37(5), 442-451.

Beirne, P. (1995). The use and abuse of animals in criminology: a brief history and current review. Social Justice 22, $5-31$ 
Beirne, P. (1997). Rethinking bestiality: towards a concept of interspecies sexual assault. Theoretical Criminology 1, 317-340.

Beirne, P. (1999). For a non-speciest criminology: animal abuse as an object of study. Criminology 37, 117-147.

Berk, R.A. (1990). Thinking about Hate-motivated Crimes, Journal of Interpersonal Violence 5, 334-340.

Black, D. (1983). Crime as Social Control, American Sociological Review, 48:1, 34-45

Black, D. (2008). Terrorism as Social Control. In Ed. DeFlem, M., Terrorism and Counter Terrorism Criminological Perspectives. (pp. 1-8) Amsterdam: Elsevier

Blair, B.G. and Brewer, G.D. (1977). The Terrorist Threat to World Nuclear Programs. The Journal of Conflict Resolution 21, 379-403.

Bodansky, Y. (2001). Bin Laden: The Man who Declared War on America. New York: Forum.

Burgess, R.L. and Akers, R.L. (1966). A Differential Association-Reinforcement Theory of Criminal Behavior. Social Problems, 14, 128-147.

Carter, David L. (1994). International Organized Crime: Emerging Trends in Entrepreneurial Crime. Journal of Contemporary Criminal Justice 10, 239- 265

Carson, D., Sullivan, C., Cochran, J., \& Lersch, K. (2009). General Strain Theory and the Relationship Between Early Victimization and Drug Use. Deviant Behavior, 30(1), 54-88.

Chabat, Jorge (2002). Mexico's War on Drugs: No Margin for Maneuver. Annals of the American Academy of Political and Social Science 582, 134-148

Chermak, S. (2003). Marketing fear: representing terrorism after September 11. Journal for Crime, Conflict and the Media 1, 5-22.

Cloward, R.A. and Ohlin, L.E. (1960). Delinquency and Opportunity: A Theory of Gangs. New York: The Free Press.

Cohen, A.K. (1955). Delinquent Boys: The Culture of the Gang. New York: The Free Press.

Combs, C.C. (2006). The media as a showcase for terrorism. In Forest, J.F. ed. Teaching Terror: Strategic and Tactical Learning in the Terrorist World (pp. 133-144) New York: Rowman \& Littlefield Publishers, Inc.

Corsi, J.R. (1981). Terrorism as a Desperate Game: Fear, Bargaining, and Communication in the Terrorist Event. The Journal of Conflict Resolution 25, 47-85.

Costello, B., Anderson, B., and Stein, M. (2006). Heavy Episodic Drinking Among Adolescents: A Test of Hypotheses Derived from Control Theory. Journal of Alcohol \& Drug Education, 50(1), 35-55

Coughlin, K. (2007). A cyberworld of hate, terror and jihad. The Star Ledger Retrieved April 3, 2009 from http://blog.nj.com/ledgerarchives/2007/05/a_cyberworld_of_hate_terror_an_1.html

Craine, J., Tanaka, T., Nishina, A., \& Conger, K. (2009). Understanding Adolescent Delinquency: The Role of Older Siblings' Delinquency and Popularity with Peers. Merrill-Palmer Quarterly, 55(4), 436-453.

Crenshaw, M. (1998). The logic of terrorism: Terrorist behavior as a product of strategic choice. In Reich, W. ed. Origins of Terrorism: Psychologies, ideologies, theologies, states of mind. (pp. 7-24). Washington D.C.: Woodrow Wilson Center Press.

Cullen, F.T. (1988). Were Cloward and Ohlin strain theorists? Delinquency and opportunity revisited. Journal of Research in Crime and Deliquency 25, 214-241

Damphousse, K.R. and Shields C. (2007). The Morning after assessing the effect of major terrorism events on prosecution strategies and outcomes. Journal of Contemporary Criminal Justice, 23,174-194.

DeFlem, M. (2004). Introduction: towards a criminological sociology of terrorism and counter-terrorism. In ed. DeFlem, M., Terrorism and Counter Terrorism Criminological Perspectives. (pp. 1-8) Amsterdam: Elsevier

DeFlem, M. (2005). Reading terrorism and terrorists, review essay Theoretical Criminology 9:231-236

Desker, B. and Ramakrishna, K. (2002). Forging an Indirect Strategy in Southeast Asia. Washington Quarterly, 25,161-76.

Dreyfus, Pablo G. (1999). When All Evils Come Together, Cocaine, Corruption and Shining Path in Peru's Upper Huallaga Valley, 1980 to 1995. Journal of Contemporary Criminal Justice 15(4), 370-396

Dulin, A. (2006). Terrorism and the Criminal Threat to Civil Aviation, Office of International Criminal Justice, Sam Houston State University Press.

Elliott, P. (1998). Brotherhoods of Fear: A History of Violent Organizations London: Blandford.

Engel B.A. and Rosenthal C.N. (1987). Five Sisters: Women Against the Tsar,_London: Routledge.

Etzioni, A. (2009). Terrorists Neither Soldiers nor Criminals Military Review July-August. 108-118.

Felix, E.D., Furlong, M.J., and Austin, G. (2009). A Cluster Analytic Investigation of School Violence Victimization Among Diverse Students. Journal of Interpersonal Violence, 24 (10), 1673-1695. 
Ferracuti, F. (1998). Ideology and repentance: Terrorism in Italy. In Reich, W. ed. Origins of Terrorism: Psychologies, ideologies, theologies, states of mind. (pp. 59-64). Washington D.C.: Woodrow Wilson Center Press.

Figner, V.N. (1991). Memoirs of a Revolutionist Chicago: Northern Illinois University Press.

Follain, J. (1998). Jackal: The Complete Story of the Legendary Terrorist, Carlos the Jackal. New York: Arcade Publishing.

Forest, J.F. (2006). Training camps and other centers of learning. In Forest, J.F. ed. Teaching Terror: Strategic and Tactical Learning in the Terrorist World (pp. 69-109) New York: Rowman \& Littlefield Publishers, Inc.

Fuentes, Joseph R. and Robert J. Kelly (1999). Drug Supply and Demand, The Dynamics of the American Drug Market and Some Aspects of Colombian and Mexican Drug Trafficking. Journal of Contemporary Criminal Justice 15, 328-351

Garrison, A.H. (2004). Defining Terrorism: Philosophy of the Bomb, Propaganda by Deed and Change Through Fear and Violence. Criminal Justice Studies, 17, 259-279

George, J. and Wilcox, L. (1996). American Extremists: Militias, Supremacists, Klansmen, Communists, \& Others. Amherst, NY: Prometheus Books

Gershman, (2002). Is Southeast Asia the Second Front? Foreign Affairs 81, 60-74.

Glaser, D. (1956). Criminality Theories and Behavioral Images. American Journal of Sociology 61 433-44.

Gleis, J.L. (2007). Israel's struggle against Palestinian Terrorist Organizations. In Forest, J.J.F. ed. Countering Terrorism and Insurgency in the $21^{\text {st }}$ Century: International Perspectives: Lessons from the Fight Against Terrorism, Volume 3. (pp. 408-429). London: Praeger Security International.

Goodwin, J. (2006). A theory of categorical terrorism. Social Forces 84(4), 2027-2046.

Gurr, T.R. (1998). Terrorism in democracies: Its social and political bases. In Reich, W. ed. Origins of Terrorism: Psychologies, ideologies, theologies, states of mind. (pp. 86-102). Washington D.C.: Woodrow Wilson Center Press.

Hall, R.E. (2009). Cool Posse, Black Manhood and Juvenile Delinquency. Journal of Human Behavior in the Social Environment, 19 (5), 531-539.

Hamm, M.S. (1994). American Skinheads: The Criminology and Control of Hate Crime, Westport, Conn: Greenwood Publishing Group.

Hamm, M.S. (2004). Apocalyptic violence: The seduction of terrorist subcultures Theoretical Criminology 8, 323339.

Hamm, M.S. (2007). From Oklahoma City to Al-Qaeda and Beyond Terrorism as Crime New York: New York University Press

Hamm, M. \& Van de Voorde, C. (2005). Crimes committed by terrorist groups: theory, research, and prevention Trends in Organized Crime, 9(2), 18-51.

Hess, H. (2003). 'Like Zealots and Romans: Terrorism and Empire in the 21st Century', Crime, Law and Social Change, Vol. 39, pp. 339-357.

Hewitt, C. (2000a). The political context of terrorism in America: ignoring extremists or pandering to them? Terrorism and Political Violence 12, 325-344.

Hewitt, C. (2000b). Patterns of American terrorism 1955-1998: an historical perspective on terrorism-related fatalities. Terrorism and Political Violence 12, 1-14.

Hirschi, Travis (1969). Causes of Delinquency. Berkeley: University of California Press.

Hudson, R.A. (1999). Who becomes a terrorist and why: the 1999 government report on profiling terrorists. Guilford, CT: The Lyons Press.

Ireland, T. \& Smith, C. (2009). Living in Partner-violent Families: Developmental Links to Antisocial Behavior and Relationship Violence. Journal of Youth \& Adolescence, 38(3), 323-339.

Jacobs, R. (1997). The Way the Wind Blew: A History of the Weather Underground, London: Verso.

Jennings, W., Piquero, N., Gover, A., \& Pérez, D. (2009). Gender and general strain theory: A replication and exploration of Broidy and Agnew's gender/strain hypothesis among a sample of southwestern Mexican American adolescents. Journal of Criminal Justice, 37(4), 404-417.

Josephson, W.L. and Proulx, J.B. (2008). Violence in Young Adolescents' Relationships. Journal of Interpersonal Violence, 23( 2),189-208.

Kasczinski, T. The Unabomber Manifesto, Retrieved October 23, 2008 from http://cyber.eserver.org/unabom.txt.

Kellen, K. (1998). Ideology and rebellion: Terrorism in West Germany. In Reich, W. ed. Origins of Terrorism: Psychologies, ideologies, theologies, states of mind. (pp. 43-58). Washington D.C.: Woodrow Wilson Center Press. 
Koffman, S., Ray, A., Berg, S., Covington, L., Albarran, N., \& Vasquez, M. (2009). Impact of a Comprehensive Whole Child Intervention and Prevention Program among Youths at Risk of Gang Involvement and Other Forms of Delinquency. Children \& Schools, 31(4), 239-245

Kramer, M. (1998). The moral logic of Hizballah. In Reich, W. ed. Origins of Terrorism: Psychologies, ideologies, theologies, states of mind. (pp. 131-160). Washington D.C.: Woodrow Wilson Center Press.

Krieger, D. (1977). What Happens If...? Terrorists, Revolutionaries, and Nuclear Weapons. Annals of the American Academy of Political and Social Science 430, 44-57.

Kupperman, R.H., Opstal, D.V., Williamson, Jr., D. (1982). Terror, the Strategic Tool: Response and Control. Annals of the American Academy of Political and Social Science, International Terrorism, 463, 24-38.

Lafree G. and Dugan L. (2007). How does studying terrorism compare to studying crime? In ed. DeFlem, M., Terrorism and Counter Terrorism Criminological Perspectives. (pp. 53-74). Amsterdam: Elsevier

Lafree, G., Dugan, L., and Korte, R. (2009). The impact of British counterterrorist strategies on political violence in Northern Ireland: comparing deterrence and backlash models. Criminology, 47, 17-46.

Levin, B. (2007). Trials for terrorists: The shifting legal landscape of the post-9/11 era. Journal of Contemporary Criminal Justice 23, 195-218.

Lo, C., Kim, Y., \& Church, W. (2008). The Effects of Victimization on Drug Use: A Multilevel Analysis. Substance Use \& Misuse, 43(10), 1340-1361.

Manasse, M.E. and Ganem, N.M. (2009). Victimization as a cause of delinquency: The role of depression and gender. Journal of Criminal Justice 37: 4, pp. 371-378

Maume, M., Ousey, G., \& Beaver, K. (2005). Cutting the Grass: A Reexamination of the Link between Marital Attachment, Delinquent Peers and Desistance from Marijuana Use. Journal of Quantitative Criminology, 21(1), 27-53.

Melde, C. and Esbensen, F. (2009). The Victim--Offender Overlap and Fear of In-School Victimization: A Longitudinal Examination of Risk Assessment Models. Crime \& Delinquency, 55 (4), 499-525

Merari,A. (1998). The readiness to kill and die: Suicidal terrorism in the Middle East. In Reich, W. ed. Origins of Terrorism: Psychologies, ideologies, theologies, states of mind. (pp. 192-210). Washington D.C.: Woodrow Wilson Center Press.

Merton, R.K. (1938). Social Structure and Anomie. American Sociological Review 3, 672-682.

Merton, R.K. (1968). Social Theory and Social Structure. New York: The Free Press.

McGarrell, E.F., Freilich, J.D., and Chermak, S. (2007) Intelligence-Led Policing as a Framework for Responding to Terrorism. Journal of Contemporary Criminal Justice, May 2007; 23: 142 - 158

McVeigh, T. Unpublished Essays. Retrieved October 23, 2008 from

http://www.outpost-of-freedom.com/mcveigh/okcaug98.htm.

Melroy, J.R. and McEllistrem, J.E. (1998). Bombing and psychopathy: An integrative review. Journal of Forensic Science 43, 556-562

Miller, A. (2006a). The terrorist mind. I. A psychological and political analysis. International Journal of Offender Therapy and Comparative Criminology 50, 121-138

Miller, A. (2006b). The terrorism mind. II. Typologies, psychopathologies and practical guidelines for investigation. International Journal of Offender Therapy and Comparative Criminology 50, 255-268

Mythen, G.and Walklate, C. (2006). Criminology and Terrorism: Which Thesis? Risk Society or Governmentality? The British Journal of Criminology, 46(3), 379-398.

Oberschall, A.(2004).Explaining Terrorism: The Contribution of Collective Action Theory*.Sociological Theory, 22(1), 26-37.

Oliverio, A. (1997). The state of Injustice: The Politics of Terrorism and the Production of Order. International Journal of Comparative Sociology, 38, 48-63.

Pape, R.A. (2005). Dying to Win, The Strategic Logic of Suicide Terrorism, New York: Random House

Passas, N. (1990). Anomie and corporate deviance. Contemporary Crises, 14, 157-178

Passas, N. (1995). Continuities in the anomie tradition. In eds. Adler, F. and Laufer, W.S. The Legacy of Anomie Theory Advances in Criminological Theory (pp. 91-112), New Brunswick: Transaction Publishers

Price, Jr., H.E. (1977). The Strategy and Tactics of Revolutionary Terrorism Comparative Studies in Society and History 19, 52-66.

Ramakrishna, K. (2006). The Making of the Jemaah Islamiyah Terrorist. In Forest, J.F. ed. Teaching Terror: Strategic and Tactical Learning in the Terrorist World (pp. 223-260) New York: Rowman \& Littlefield Publishers, Inc. 
Rapoport, D.C. (1998). Sacred Terror: A contemporary example from Islam. In Reich, W. ed. Origins of Terrorism: Psychologies, ideologies, theologies, states of mind. (pp. 103-130). Washington D.C.: Woodrow Wilson Center Press.

Reckless, W.C. (1967). The Crime Problem. Fourth edition. New York: Meredith.

Ripley, A. (2007). The Fort Dix Conspiracy. Time Retrieved April 3, 2009 from http://www.time.com/time/nation/article/0,8599,1691609,00.html

Rosenfeld, R. (2008). Terrorism and Criminology. In ed. DeFlem, M., Terrorism and Counter Terrorism Criminological Perspectives. (pp. 19-32) Amsterdam: Elsevier

Rosenfeld, R. (2002). Why Criminologists Should Study Terrorism. The Criminologist 1, 3-4.

Ross, J.I. (1993). Structural Causes of Oppositional Political Terrorism: Towards a Causal Model. Journal of Peace Research 30, 317-329.

Ruby, C. (2002). Are Terrorists Mentally Deranged? Analyses of Social Issues \& Public Policy, 2(1), 15-26.

Russell, C.A. and Miller, B.H. (1977). Profile of a Terrorist. Terrorism: An International Journal 1, 17-34.

Ryan, J., Testa, M., \& Fuhua, Z. (2008). African American Males in Foster Care and the Risk of Delinquency: The Value of Social Bonds and Permanence. Child Welfare, 87(1), 115-140.

Silke, A. (2008). Holy warriors: Exploring the psychological processes of Jihadi radicalization. European Journal of Criminology 5, 1477-3708.

Smith, B., Damphousse, K., Jackson, F.and Sellers, A. (2002). The prosecution and punishment of international terrorists in federal courts: 1980-1998. Criminology and Public Policy 36, 311-338.

Smith, B.L. (1994). Terrorism in America: Pipe bombs and pipe dreams. Albany: State University of New York Press.

Smith, B.L. and Damphousse, K. (1998). Terrorism, politics, and punishment: A test of structural-contextual theory and the "liberation hypothesis". Criminology, 36(1), 67-92.

Sprinzak, E. (2000). Rational Fanatics. Foreign Policy 120, 66-73.

Sutherland, E.H. (1924). Criminology. Philadelphia: J.B.Lippincott.

Sykes, G.M. and Matza, D. (1957). Techniques of Neutralization. American Sociological Review 22,664-670.

Thoumi, Francisco E. (2002). Illegal Drugs in Colombia: From Illegal Economic Boom to Social Crisis. Annals of the American Academy of Political and Social Science 582, 102-116

Toby, J. (1957). Social Disorganization and Stake in Conformity: complementary factors in the predatory behavior of hoodlums. Journal of Criminal Law, Criminology and Police Science, 48, 12-17.

Torres, M.R., Jordan, J. and Horsburgh, N. (2006). Analysis and Evolution of the Global Jihadist Movement Propaganda. Terrorism and Political Violence, 18, 399-421

Turk, A. (1982). Political Criminality: The defiance and defense of authority Beverley Hills, CA: Sage Publications.

Turk, Austin T. (1969). Criminality and the Legal Order. Chicago: Rand McNally.

(1977). Deterring Airport Terrorist Attacks and Compensating the Victims University of Pennsylvania Law Review $125,1134-1165$.

Vague, T. (1994). Televisionaries: The red army faction story, 1963-1993 Oakland, CA: AK Press.

Varon, J. (2004). Bringing the War Home: The Weather Underground, the Red Army Faction, and Revolutionary Violence in the Sixties and Seventies Berkley: University of California Press.

Weber, M. (1949). The Methodology of the Social Sciences. New York: Free Press.

Weber, M. (2001). The Protestant Ethic and the Spirit of Capitalism. London: Taylor \& Francis, Inc.

Weinberg, L. (1991). Turning to Terror: The Conditions under Which Political Parties Turn to Terrorist Activities Comparative Politics 23, 423-438.

Weinman, G. (2006). Terror on the Internet. Washington D.C.: United States Institute of Peace Press.

Weinman, G. (2006). Virtual training camps: terrorists' use of the Internet. In Forest, J.F. ed. Teaching Terror: Strategic and Tactical Learning in the Terrorist World (pp. 110-132) New York: Rowman \& Littlefield Publishers, Inc.

Willis, H.H., Morral, A.R., Kelly, T.K. and Medby, J.J. (2005). Estimating Terrorism Risk RAND Center for Terrorism Risk Management Policy.

Wilson, M.A. (2000). Toward a Model of Terrorist Behavior in Hostage-Taking Incidents The Journal of Conflict Resolution 44, 403-424.

Wilson, W.J. (1987). The Truly Disadvantaged: The Inner City, the Underclass, and Public Policy. Chicago: University of Chicago Press.

Worrall, J.L. (1999). Focusing event: characteristics and issue accompaniment: the case of domestic terrorism. Criminal Justice Policy Review 3, 319-341. 
Zahn M.A. and Strom, K.J. (2007). Terrorism and the federal social science research agenda. In ed. DeFlem, M., Terrorism and Counter Terrorism Criminological Perspectives. (pp. 111-130) Amsterdam: Elsevier

[1] A struggle, one of the duties of a Muslim. Some explain this struggle as an internal striving to uphold one's beliefs and the teachings of Mohamed, while others express jihad as a physical struggle to the point of warfare with nonbelievers.

[2] This is a subject of considerable debate. One translation is that a fatwa is a religious, scholarly interpretation of Islamic law, often including edicts and/or conditions that must be satisfied, which identifies what is allowed and what is forbidden activity, behavior and involvement for Muslims. Fatwas are not universally binding; adherence varies according to many factors including sect and geographical region.

[3] Martyrdom, usually by engaging in militaristic acts.

[4] A term for self-sacrifice to separate martyrs from suicides, as suicide is forbidden under Islamic tenets.

[5] Never the official name of the organization. "The Baader-Meinhof gang" was a name given to the Red Army Faction by state media after journalist Ulrike Meinhof assisted the Red Army Faction in their operation to free Andreas Baader: an event that cemented her participation in anarchist and terrorist activities, although the group itself viewed her as more of a "hanger-on" than a true member and especially not an individual in a leadership position (Varon, 2004). 